\title{
Characterization of Phosphorus in Subtropical Coastal Sand Dune Forest Soils
}

\author{
Chiao-Wen Lin ${ }^{1} \mathbb{D}$, Guanglong Tian ${ }^{2}$, Chung-Wen Pai ${ }^{3}$ and Chih-Yu Chiu ${ }^{1, *(\mathbb{D})}$ \\ 1 Biodiversity Research Center, Academia Sinica, Nangang, Taipei 11529, Taiwan; clin10@ncsu.edu \\ 2 Environmental Monitoring and Research Division, Monitoring and Research Department, Metropolitan \\ Water Reclamation District of Greater Chicago, 6001 W. Pershing Road, Cicero, IL 60804, USA; \\ TianG@mwrd.org \\ 3 The Experimental Forest, College of Bio-Resource and Agriculture, National Taiwan University, \\ Nantou 55743, Taiwan; cwpai724@yahoo.com.tw \\ * Correspondence: bochiu@sinica.edu.tw; Tel.: +886-2-2787-1180
}

Received: 12 September 2018; Accepted: 12 November 2018; Published: 15 November 2018

\begin{abstract}
Continuous research into the availability of phosphorus $(\mathrm{P})$ in forest soil is critical for the sustainable management of forest ecosystems. In this study, we used sequential chemical extraction and ${ }^{31} \mathrm{P}$-nuclear magnetic resonance spectroscopy $\left({ }^{31} \mathrm{P}-\mathrm{NMR}\right)$ to evaluate the form and distribution of inorganic $\mathrm{P}\left(\mathrm{P}_{\mathrm{i}}\right)$ and organic $\mathrm{P}\left(\mathrm{P}_{\mathrm{o}}\right)$ in Casuarina forest soils of a subtropical coastal sand dune in Houlong, Taiwan. The soil samples were collected from humic $(+2-0 \mathrm{~cm})$ and mineral layers (mineral-I: 0-10, mineral-II: 10-20 cm) at two topographic locations (upland and lowland) with different elevations. Sequential chemical extraction revealed that the $\mathrm{NaOH}-\mathrm{P}_{\mathrm{o}}$ fraction, as moderately recalcitrant $\mathrm{P}$, was the dominant form in humic and mineral-I layers in both upland and lowland soils, whereas the cHCl- $\mathrm{P}_{\mathrm{i}}$ fraction was the dominant form in the mineral-II layer. The resistant $\mathrm{P}$ content, including NaOH- $\mathrm{P}_{\mathrm{i}}, \mathrm{HCl}-\mathrm{P}_{\mathrm{i}}, \mathrm{cHCl}-\mathrm{P}_{\mathrm{i}}$, and cHCl- $\mathrm{P}_{\mathrm{o}}$ fractions, was higher in the upland than in the lowland. However, the labile $\mathrm{P}$ content, $\mathrm{NaHCO}_{3}-\mathrm{P}_{\mathrm{o}}$, showed the opposite pattern. The content of resistant $\mathrm{P}_{\mathrm{i}}\left(\mathrm{NaOH}-\mathrm{P}_{\mathrm{i}}, \mathrm{HCl}-\mathrm{P}_{\mathrm{i}}\right.$, and cHCl- $\left.\mathrm{P}_{\mathrm{i}}\right)$ increased significantly with depth, but that of labile $\mathrm{P}_{\mathrm{i}}$ (resin- $\mathrm{P}_{\mathrm{i}}$ and $\left.\mathrm{NaHCO}_{3}-\mathrm{P}_{\mathrm{i}}\right)$ and recalcitrant $\mathrm{P}_{\mathrm{o}}\left(\mathrm{NaHCO}_{3}-\mathrm{P}_{\mathrm{o}}, \mathrm{NaOH}-\mathrm{P}_{\mathrm{o}}\right.$, and cHCl- $\left.\mathrm{P}_{\mathrm{o}}\right)$ decreased significantly with depth at both locations. ${ }^{31} \mathrm{P}-\mathrm{NMR}$ spectroscopy revealed inorganic orthophosphate and monoesters-P as the major forms in this area. The proportions of $P_{i}$ and $P_{o}$ evaluated by sequential chemical extraction and ${ }^{31} \mathrm{P}-\mathrm{NMR}$ spectroscopy were basically consistent. The results indicate that the soils were in weathered conditions. Furthermore, the P distribution and forms in this coastal sand dune landscape significantly differed between the upland and lowland because of the variation in elevation and eolian aggradation effects.
\end{abstract}

Keywords: sequential chemical extraction; ${ }^{31} \mathrm{P}$-nuclear magnetic resonance spectroscopy $\left({ }^{31} \mathrm{P}-\mathrm{NMR}\right)$; phosphorus; coastal sand dune; Casuarina forests

\section{Introduction}

Phosphorus (P) plays an essential role in nutrient cycles [1] and the availability of $\mathrm{P}$ in soil is controlled by biogeochemical processes [2]. However, many studies overlook $\mathrm{P}$ in soil organic matter [1]. Compared with nitrogen, which can be replenished through biological $\mathrm{N}_{2}$ fixation, the sources of the total $\mathrm{P}$ content are weathering bedrocks and atmospheric deposits [3], and the loss of $\mathrm{P}$ due to leaching or conversion into occluded $\mathrm{P}$ can be replenished by a weathering process [4]. The phosphorus dynamics and availability in the soil are determined by soil properties, soil types, parent materials, vegetation, environmental conditions, and land management practices [5]. 
Organic $\mathrm{P}\left(\mathrm{P}_{\mathrm{o}}\right)$ is important in biogeochemical cycling [6]. $\mathrm{P}_{\mathrm{o}}$ is found in a variety of compounds in the soil environment with different stabilities and biological availabilities [3,7]. The chemical composition of $\mathrm{P}$ and plants/microbes have interactive effects on one another [3]. When the inorganic $\mathrm{P}\left(\mathrm{P}_{\mathrm{i}}\right)$ content decreases, microbial communities can decompose $\mathrm{P}_{\mathrm{o}}$ to replenish the limited $\mathrm{P}_{\mathrm{i}}$. Furthermore, the $P_{o}$ and $P_{i}$ contents are correlated with the soil mineral content (e.g., iron $(\mathrm{Fe})$, aluminum (Al)) because $\mathrm{P}$ is either bound to or released from the soil minerals in different redox conditions [8,9]. Determining the relationship between $P_{i}$ and $P_{o}$ is important to understand $P$ availability and to predict soil development [4]. The microbial respiration rate and organic matter decomposition were found to be affected by the amounts of $\mathrm{P}$, labile carbon $(\mathrm{C})$, and nitrogen $(\mathrm{N})$ in the soil [10]. We need to understand the sources and transformations of $\mathrm{P}_{\mathrm{o}}$ because they can provide information on how to develop sustainable management practices and predict nutrient changes (e.g., C:N:P) and biogeochemistry processes [11].

Hedley et al. [12] developed chemical fractionation techniques to quantify different pools of $P$ based on different biological availabilities and used the sequential chemical extraction method to estimate subtle changes in P pools in cultivated field soil. The chemical sequential extraction results for $\mathrm{P}$ were used to evaluate mineralization, microbial turnover, and plant-utilization mechanisms and to compare them with carbon and nitrogen dynamics [13]. However, sequential chemical extraction could not evaluate the structural composition of the different $\mathrm{P}$ forms; thus, ${ }^{31} \mathrm{P}-\mathrm{NMR}$ spectroscopy was developed to improve on the deficiencies $[2,14]$. In fact, ${ }^{31} \mathrm{P}-\mathrm{NMR}$ spectroscopy is less complicated to use than chemical extraction methods for characterizing organic P $[15,16]$. Furthermore, it can be difficult to compare the research results when different chemical extractants are used [11]; thus, ${ }^{31} \mathrm{P}-\mathrm{NMR}$ has been widely used to quantify soil organic $\mathrm{P}$ and compare the $\mathrm{P}$ forms with standard extractants (e.g., $\mathrm{NaOH}-\mathrm{ETDA})[17,18]$.

Sand dune landscapes are typical on the western coast of Taiwan, and Casuarinas forests were planted 8 decades ago to stabilize these sand dunes and preserve their inland vegetation [19]. This type of forest was grown in a hostile environment, which included cases of droughts, low fertility, and high soil salinity. This region is also in a subtropical area with a high temperature and an abundant rainfall; the soil is weakly developed from sand and has a low water-holding capacity. Because P is often limited in forest ecosystems [20-22], we needed to evaluate the concentration of $P$ available to plants and characterize the availability of organic $P$ in these ecosystems [23].

Several studies have characterized the $\mathrm{P}$ dynamics and distributions through either chemical sequential extraction or ${ }^{31}$ P-NMR spectroscopy in tropical forests [24-26], subtropical forests [27,28], and temperate forests [4,23]. Negassa and Leinweber [29] indicated that only a few studies have characterized $\mathrm{P}$ in soils by comparing ${ }^{31} \mathrm{P}-\mathrm{NMR}$ and sequential chemical extraction. Thus, more natural ecosystems and anthropogenic field experiments are required to evaluate the basic principles and mechanisms of $\mathrm{P}$ transformation [11]. Although several authors have investigated $\mathrm{P}$ distribution and forms in sand dune forest soils in temperate areas [3,4], our research is—-to our knowledge- the first to characterize $P$ in a subtropical sand dune forest.

In this study, we hypothesized that the P distribution and forms are different between two sand dune topologies (upland and lowland) and that the variation in soil conditions and biogeochemical processes between these topologies account for these differences. Thus, the main objective of this research was to characterize and compare the P composition between two different topographies in a sand dune ecosystem by using sequential chemical extraction and ${ }^{31} \mathrm{P}-\mathrm{NMR}$ methods.

\section{Materials and Methods}

\subsection{Site Description}

The study site was the coastal sand dune forests at Houlong, Miaoli County, northwestern Taiwan $\left(24^{\circ} 39^{\prime} \mathrm{N}, 121^{\circ} 54^{\prime} \mathrm{E}\right)$. The mean annual temperature was $22.4^{\circ} \mathrm{C}$. The climate is hot and wet in the summer (mean temperature $28.6^{\circ} \mathrm{C}$ ) and mild and dry in the winter (mean temperature $16.3^{\circ} \mathrm{C}$ ). The mean annual rainfall is about $1700 \mathrm{~mm}$, with a rainy season from February to August. 
The rainfall is relatively low from September to January. Casuarina spp., the dominant vegetation, was established more than 8 decades ago to protect the inland plants and stabilize the sand dunes. Coastal hibiscus (Hibiscus tiliaceus L.) and paper mulberry (Broussonetia papyrifera (L.) Vent.) are less dominant tree species. Sage (Lantana camara L.), as an understory shrub, distributes commonly in the forests. According to the topography of the sand dune forests, the study site was separated into two locations: upland and lowland. Upland areas are distributed on the flat ridges of the sand dune and lowland areas face the inland side. The average slope between the uplands and lowlands is $5 \%$ and the distance and mean elevation values between the two locations are about $200 \mathrm{~m}$ and $6 \mathrm{~m}$, respectively.

The soils at the two locations are classified as Typic Udipsamment, meaning they contain a very shallow litter layer $(1-2 \mathrm{~cm})$ and a humic layer $(2-3 \mathrm{~cm})$ on weakly developed sandy soil $[19,30]$. Soil samples were collected from three layers-humic $(+2-0 \mathrm{~cm})$, mineral-I $(0-10 \mathrm{~cm})$, and mineral-II $(10-20 \mathrm{~cm})$ - at the uplands and lowlands. The general soil's physical and chemical properties of the study site are summarized in Table 1 . The soil texture was sand, and the soil $\mathrm{pH}$ values increased with depth at both locations. In addition, the content of organic carbon $(\mathrm{C})$, total nitrogen $(\mathrm{N})$, cation exchange capacity (CEC), and moisture was highest in the humic layer and decreased sharply in the two mineral layers. The contents of crystalline iron $\left(\mathrm{Fe}_{\mathrm{d}}\right)$ oxides, crystalline aluminum $\left(\mathrm{Al}_{\mathrm{d}}\right)$ oxides, amorphous iron $\left(\mathrm{Fe}_{\mathrm{o}}\right)$ oxides, and amorphous aluminum $\left(\mathrm{Al}_{\mathrm{o}}\right)$ oxides were similar in the two mineral layers. Because both locations are close, the climate features and mineral compositions of the parent material were similar. Thus, the typographic variations might be the most important factors causing the different distribution of $\mathrm{P}$ forms.

Table 1. The general physical and chemical properties of the studied coastal forest soils.

\begin{tabular}{|c|c|c|c|c|c|c|c|c|c|c|c|c|c|c|}
\hline \multirow{2}{*}{ Site } & \multirow{2}{*}{ Layer } & \multirow{2}{*}{ Texture } & \multirow{2}{*}{$\frac{\mathrm{pH}}{\left(\mathrm{H}_{2} \mathrm{O}\right)}$} & \multicolumn{2}{|c|}{ Organic C } & \multicolumn{2}{|c|}{ Total N } & \multicolumn{2}{|c|}{ Moisture } & \multirow{2}{*}{$\frac{\text { CEC }}{\left(\mathrm{cmol}_{(+)} \mathrm{kg}^{-1}\right)}$} & \multirow{2}{*}{$\frac{\mathrm{Fe}_{\mathrm{d}}}{(\mathrm{g} / \mathrm{kg})}$} & \multirow{2}{*}{$\frac{\mathrm{Fe}_{\mathrm{o}}}{(\mathrm{g} / \mathrm{kg})}$} & \multirow{2}{*}{$\frac{A 1_{d}}{(g / k g)}$} & \multirow{2}{*}{$\frac{\mathrm{Al}_{\mathrm{o}}}{(\mathrm{g} / \mathrm{kg})}$} \\
\hline & & & & & & & & $(\%$ & & & & & & \\
\hline \multirow[b]{2}{*}{ Upland } & $\begin{array}{l}\text { Humic } \\
(+2-0 \mathrm{~cm})\end{array}$ & - & 4.2 & 16.2 & A & 1.2 & A & 45.0 & A & 45.0 & - & - & - & - \\
\hline & $\begin{array}{l}\text { Mineral-I } \\
(0-10 \mathrm{~cm})\end{array}$ & Sand & 4.9 & 1.1 & $\mathrm{~b}$ & 0.1 & $\mathrm{~b}$ & 3.7 & $\mathrm{a}$ & 7.9 & 5.8 & 1.6 & 1.5 & 0.7 \\
\hline \multirow{3}{*}{ Lowland } & $\begin{array}{l}\text { Humic } \\
(+2-0 \mathrm{~cm})\end{array}$ & - & 4.2 & 9.6 & B & 0.7 & B & 27.6 & B & 13.1 & - & - & - & - \\
\hline & $\begin{array}{l}\text { Mineral-I } \\
(0-10 \mathrm{~cm})\end{array}$ & $\begin{array}{l}\text { Loamy } \\
\text { sand }\end{array}$ & 4.7 & 1.4 & a & 0.1 & a & 5.0 & $\mathrm{a}$ & 2.8 & 4.6 & 1.3 & 1.9 & 0.6 \\
\hline & $\begin{array}{l}\text { Mineral-II } \\
(10-20 \mathrm{~cm})\end{array}$ & Sand & 5.2 & 0.3 & c & 0.1 & c & 4.1 & $\mathrm{a}$ & 2.1 & 5.3 & 1.5 & 1.7 & 0.8 \\
\hline
\end{tabular}

Soil $\mathrm{pH}$, organic $\mathrm{C}$, total $\mathrm{N}$ contents and moisture were adapted from Chen et al. [19]; values followed by the same letters in each column are not significantly different $(p>0.05)$ based on Duncan's multiple range test; capital letters and lowercase letters represent humic and soil mineral layers, respectively.

\subsection{Soil Sampling}

At the two locations, one composite sample was collected from each of the three layers. Soil samples in the humic layer $(+2-0 \mathrm{~cm})$ were collected with $50 \times 50 \mathrm{~cm}$ quadrats after undecomposed litter/roots were carefully removed. The samples underneath the mineral layers (mineral-I $(0-10 \mathrm{~cm})$ and mineral-II $(10-20 \mathrm{~cm})$ ) were collected using a soil auger with a $4.25-\mathrm{cm}$ diameter. Before the soil samples were sieved through a 2-mm sieve, the litter/roots were manually removed from the samples. The soil samples were then air-dried.

\subsection{Sequential Chemical Extraction of Soil P}

A method for the sequential chemical extraction of $P$ [31] was used to obtain various $P_{i}$ and $P_{o}$ forms. The general concept for the $\mathrm{P}$ fractionation method is based on how $\mathrm{P}$ reacts to specific reagents. The extraction procedure began with $0.5 \mathrm{~g}$ of air-dried soil. First, an anion exchange resin was applied to extract part of labile $P_{i}[24,27,32]$, then the remaining soil sample was extracted by applying $0.5 \mathrm{M}$ 
$\mathrm{NaHCO}_{3}, 0.1 \mathrm{M} \mathrm{NaOH}$, and $1 \mathrm{M} \mathrm{HCl}$ solutions sequentially. $\mathrm{NaHCO}_{3}$ and $\mathrm{NaOH}$ were used to extract $\mathrm{P}$, which was adsorptive to soil colloids [33] and combined strongly with $\mathrm{Fe}$ and $\mathrm{Al}$ [13]. The $1 \mathrm{M}$ $\mathrm{HCl}$ extraction was specific for extracting Ca-associated $\mathrm{P}$ [34]. The residue was then extracted with concentrated $\mathrm{HCl}(\mathrm{cHCl})$ to evaluate $\mathrm{P}$ in stable residual pools [31] and particulate organic debris.

In each extraction, the soil-extractant solution was centrifuged at $20,000 \times g$ for $10 \mathrm{~min}$ and filtered through Whatman 42 filter paper. Then, $\mathrm{P}_{\mathrm{i}}$ in each extraction was determined by the colorimetric method with the malachite green procedure [35]. $\mathrm{P}_{\mathrm{o}}$ in each extraction was determined by subtracting $\mathrm{P}_{\mathrm{i}}$ from the total $\mathrm{P}$ in the solution. The remaining extraction was then digested with $\mathrm{H}_{2} \mathrm{SO}_{4}(97 \%)$ and $\mathrm{H}_{2} \mathrm{O}_{2}(30 \%)$ at $300{ }^{\circ} \mathrm{C}$ to determine the residual-P concentrations. The $\mathrm{P}$ fractions extracted in this study were grouped so that the data could be presented: (1) $\mathrm{P}_{\mathrm{i}}$ forms: resin- $\mathrm{P}_{\mathrm{i}}, \mathrm{NaHCO}_{3}-\mathrm{P}_{\mathrm{i}}, \mathrm{NaOH}-\mathrm{P}_{\mathrm{i}}$, HCl- $\mathrm{P}_{\mathrm{i}}$, and cHCl- $\mathrm{P}_{\mathrm{i}}$; (2) $\mathrm{P}_{\mathrm{o}}$ forms: $\mathrm{NaHCO}_{3}-\mathrm{P}_{\mathrm{o}}, \mathrm{NaOH}-\mathrm{P}_{\mathrm{o}}$, and $\mathrm{cHCl}-\mathrm{P}_{\mathrm{o}}$. The total $\mathrm{P}(\mathrm{TP})$ of the soil samples was determined by digesting the soil with $\mathrm{H}_{2} \mathrm{SO}_{4}(97 \%)$ and $\mathrm{H}_{2} \mathrm{O}_{2}(30 \%)$ at $300{ }^{\circ} \mathrm{C}$.

\section{4. ${ }^{31}$ P-NMR Measurements}

Air-dried soil ( $5 \mathrm{~g}$ ) was dispersed in $20 \mathrm{~mL}$ of $0.25 \mathrm{M} \mathrm{NaOH}-0.05 \mathrm{M}$ EDTA (1:1) for $2 \mathrm{~h}$ at $76{ }^{\circ} \mathrm{C}$. To reduce paramagnetic interference from iron and other metals, chelating resin was added to the soil mixture, then it sat for $6 \mathrm{~h}$ at room temperature. The resin was removed by filtering the soil mixture with Whatman 42 filter paper. The remaining soil mixture was centrifuged at $10,000 \times g$ for $30 \mathrm{~min}$ and the extractant was freeze-dried for storage. Then the freeze-dried extractant $(0.1 \mathrm{~g})$ was dissolved in $0.5 \mathrm{~mL}$ of $0.5 \mathrm{M} \mathrm{NaOH}$ and $0.1 \mathrm{~mL}$ of $\mathrm{D}_{2} \mathrm{O}$. Finally, the solution was transferred to a 5-mm NMR tube for ${ }^{31} \mathrm{P}-\mathrm{NMR}$ analysis [36].

The ${ }^{31} \mathrm{P}$-NMR spectra were attained at $242.86 \mathrm{MHz}$ and $25^{\circ} \mathrm{C}$ on a Bruker-600 NMR spectrometer (Billerica, MA, USA) with a $60^{\circ}$ pulse, 3.5-s delay, and 0.33-s acquisition time. To overcome the nuclear Overhauser enhancement and obtain a quantitative result, the ${ }^{31} \mathrm{P}$ spectra were proton-decoupled by applying an inverse-gated pulse sequence $[14,37]$. Depending on the P content in the alkaline extract, 500 to 2500 scans were applied to obtain an acceptable signal-to-noise ratio. Spectra were verified with a line-broadening of $20 \mathrm{~Hz}$. The chemical shift was evaluated relative to an external $85 \% \mathrm{H}_{3} \mathrm{PO}_{4} / \mathrm{D}_{2} \mathrm{O}$ standard. Quantities of P components (inorganic orthophosphate, phosphonate, orthophosphate monoesters, orthophosphate diesters, pyrophosphate, polyphosphates) were estimated by relative peak areas calculated by electronic integration $[20,36,38]$. The inorganic orthophosphate and orthophosphate monoester signals were detected based on a boundary determined from the valley between the two signals to the baseline [20].

\subsection{Statistical Analyses}

Sequential chemical extraction and ${ }^{31} \mathrm{P}-\mathrm{NMR}$ measurements were carried out in triplicate. To evaluate the main effect of two variables (location (upland and lowland) and layer (humic, mineral-I, and mineral-II)) and the interaction effect between the two variables (location $\times$ layer) for the $\mathrm{P}$ composition and forms, two-way ANOVA and Tukey's honestly significant difference (HSD) tests were applied using the $\mathrm{R}$ software (Version 3.3.3) [39]. $p<0.05$ was considered statistically significant.

\section{Results}

\subsection{Sequential Chemical Extraction of Soil P}

The concentrations and statistical results of sequential chemical P-extraction are summarized in Table 2. As stated by several authors $[28,31]$, resin- $\mathrm{P}_{\mathrm{i}}$ and $\mathrm{NaHCO}_{3}-\mathrm{P}$ are labile forms of $\mathrm{P}, \mathrm{NaOH}-\mathrm{P}$ is moderately recalcitrant, $\mathrm{HCl}-\mathrm{P}$ and $\mathrm{CHCl}-\mathrm{P}$ are recalcitrant, and residual-P is highly recalcitrant. The content of the labile $\mathrm{P}_{\mathrm{i}}$ forms (resin- $\mathrm{P}_{\mathrm{i}}$ and $\mathrm{NaHCO}_{3}-\mathrm{P}_{\mathrm{i}}$ ) decreased significantly with depth at both locations (Table 2). However, the content of NaOH-P $\mathrm{P}_{\mathrm{i}}, \mathrm{HCl}-\mathrm{P}_{\mathrm{i}}$, and $\mathrm{cHCl}-\mathrm{P}_{\mathrm{i}}$ as recalcitrant $\mathrm{P}_{\mathrm{i}}$ forms increased significantly from the humic to mineral-I and mineral-II layers at the upland and lowland sites. The content decreased with depth for all $\mathrm{P}_{\mathrm{o}}$ forms, residual-P, and TP. 
Table 2. The summary of $\mathrm{P}$ concentrations (mean values, unit: $\mathrm{mg} \mathrm{kg}^{-1}$ ) and two-way ANOVA significance tests ( $p$-value) for sequential chemical extraction.

\begin{tabular}{|c|c|c|c|c|c|c|c|c|c|c|c|c|c|c|}
\hline \multirow{2}{*}{ Site } & \multirow{2}{*}{ Layer } & \multicolumn{5}{|c|}{ Inorganic $\mathbf{P}\left(\mathbf{P}_{\mathbf{i}}\right)$} & \multirow{2}{*}{ Sum of $P_{i}$} & \multicolumn{3}{|c|}{ Organic $\mathbf{P}\left(\mathbf{P}_{\mathrm{o}}\right)$} & \multirow{2}{*}{ Sum of $P_{0}$} & \multirow{2}{*}{ Residual-P } & \multirow{2}{*}{ Sum of $P$} & \multirow{2}{*}{ TP } \\
\hline & & Resin- $P_{i}$ & $\mathrm{NaHCO}_{3}-\mathrm{P}_{\mathrm{i}}$ & $\mathrm{NaOH}-\mathrm{P}_{\mathrm{i}}$ & HCl-P ${ }_{i}$ & cHCl-P $P_{i}$ & & $\mathrm{NaHCO}_{3}-\mathrm{P}_{\mathrm{o}}$ & $\mathrm{NaOH}-\mathrm{P}_{\mathrm{o}}$ & cHCl-P $P_{0}$ & & & & \\
\hline \multirow{3}{*}{ Upland } & $\begin{array}{c}\text { Humic } \\
(+2-0 \mathrm{~cm})\end{array}$ & 60.9 & 50.0 & 18.2 & 11.5 & 28.9 & 169.5 & 85.5 & 170.1 & 55.2 & 310.8 & 78.5 & 558.8 & 633.8 \\
\hline & $\begin{array}{l}\text { Mineral-I } \\
(0-10 \mathrm{~cm})\end{array}$ & 24.5 & 22.6 & 27.5 & 19.7 & 40.0 & 134.4 & 42.7 & 55.5 & 34.8 & 132.9 & 43.3 & 310.6 & 379.1 \\
\hline & $\begin{array}{l}\text { Mineral-II } \\
(10-20 \mathrm{~cm})\end{array}$ & 13.0 & 17.4 & 48.6 & 54.3 & 54.1 & 187.4 & 16.1 & 37.3 & 12.3 & 65.7 & 22.8 & 275.9 & 275.0 \\
\hline \multirow{3}{*}{ Lowland } & $\begin{array}{c}\text { Humic } \\
(+2-0 \mathrm{~cm})\end{array}$ & 54.3 & 42.4 & 10.2 & 9.5 & 24.5 & 140.8 & 91.9 & 149.1 & 45.6 & 286.6 & 55.7 & 483.1 & 501.3 \\
\hline & $\begin{array}{l}\text { Mineral-I } \\
(0-10 \mathrm{~cm})\end{array}$ & 25.3 & 21.5 & 15.1 & 24.6 & 33.6 & 120.1 & 56.3 & 66.6 & 22.2 & 145.1 & 43.2 & 308.4 & 376.4 \\
\hline & $\begin{array}{l}\text { Mineral 2-II } \\
(10-20 \mathrm{~cm})\end{array}$ & 15.4 & 19.6 & 20.4 & 33.7 & 44.6 & 133.7 & 27.6 & 41.2 & 18.2 & 87.0 & 22.4 & 243.1 & 210.9 \\
\hline \multicolumn{15}{|c|}{ Two-Way ANOVA Significance Tests ( $p$-Value) } \\
\hline Effects & Resin- $P_{i}$ & $\mathrm{NaHCO}_{3}-\mathrm{P}_{\mathrm{i}}$ & $\mathrm{NaOH}-\mathrm{P}_{\mathrm{i}}$ & HCl-P $P_{i}$ & cHCl-P $P_{i}$ & Sum of $P_{i}$ & $\mathrm{NaHCO}_{3}-\mathrm{P}_{\mathbf{o}}$ & $\mathrm{NaOH}-\mathrm{P}_{\mathbf{o}}$ & cHCl-P ${ }_{0}$ & Sum of $P_{o}$ & Residual-P & Sum of $P$ & \multicolumn{2}{|l|}{ TP } \\
\hline Locations & 0.673 & 0.407 & $2.16 \times 10^{-7 *}$ & $4.95 \times 10^{-4 *}$ * & $0.015^{*}$ & $2.57 \times 10^{-4 *}$ & $4.22 \times 10^{-3 *}$ & 0.817 & $0.016^{*}$ & 0.711 & $7.04 \times 10^{-3 *}$ & $\begin{array}{l}1.54 \times \\
10^{-3 *} \\
\end{array}$ & \multicolumn{2}{|c|}{$1.66 \times 10^{-3 *}$} \\
\hline Layers & $3.82 \times 10^{-8 *}$ & $1.83 \times 10^{-6 *}$ & $6.03 \times 10^{-7 *}$ & $1.67 \times 10^{-10 *}$ & $2.08 \times 10^{-5 *}$ & $2.07 \times 10^{-3 *}$ & $1.62 \times 10^{-9 *}$ & $1.45 \times 10^{-7 *}$ & $1.72 \times 10^{-8 *}$ & $1.9 \times 10^{-10 *}$ & $1.46 \times 10^{-8 *}$ & $\begin{array}{c}4.3 \times \\
10^{-11 *}\end{array}$ & \multicolumn{2}{|c|}{$7.16 \times 10^{-9 *}$} \\
\hline Location $\times$ Layer & 0.366 & 0.306 & $4.34 \times 10^{-4 *}$ & $6.82 \times 10^{-6 *}$ & 0.687 & 0.068 & 0.611 & 0.302 & $4.5 \times 10^{-3 *}$ & 0.091 & $2.94 \times 10^{-3 *}$ & 0.020 & \multicolumn{2}{|c|}{$0.024 *$} \\
\hline
\end{tabular}

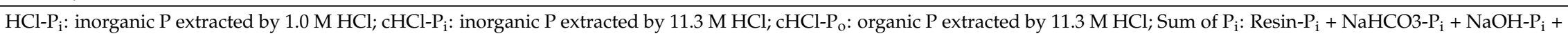

$\mathrm{HCl}-\mathrm{P}_{\mathrm{i}}+\mathrm{cHCl}-\mathrm{P}_{\mathrm{i}}$; Sum of $\mathrm{P}_{\mathrm{o}}$ : NaHCO $3-\mathrm{P}_{\mathrm{o}}+\mathrm{NaOH}-\mathrm{P}_{\mathrm{o}}+$ cHCl- $\mathrm{P}_{\mathrm{o}}$; Sum of P: summation of Resin- $\mathrm{P}_{\mathrm{i}}+\mathrm{NaHCO}_{3}-\mathrm{P}_{\mathrm{i}}+\mathrm{NaHCO}-\mathrm{P}_{\mathrm{o}}+\mathrm{NaOH}-\mathrm{P}_{\mathrm{i}}+\mathrm{NaOH}-\mathrm{P}_{\mathrm{o}}+\mathrm{HCl}-\mathrm{P}_{\mathrm{i}}+\mathrm{cHCl}-\mathrm{Pi}+\mathrm{cHCl}-\mathrm{Po}+$

residual-P; TP: by separate $\mathrm{H}_{2} \mathrm{SO}_{4} / \mathrm{H}_{2} \mathrm{O}_{2}$ digest of whole sample; *: significant difference $(p<0.05)$. 
When considering the effect of location, besides $\mathrm{NaHCO}_{3}-\mathrm{P}_{\mathrm{o}}$, the content of $\mathrm{NaOH}-\mathrm{P}_{\mathrm{i}}, \mathrm{HCl}-\mathrm{P}_{\mathrm{i}}$, cHCl- $\mathrm{P}_{\mathrm{i}}$, the sum of $\mathrm{P}_{\mathrm{i}}, \mathrm{cHCl}-\mathrm{P}_{\mathrm{o}}$, residual-P, the sum of $\mathrm{P}$, and TP were significantly higher in the upland than lowland. For the location $\times$ layer effect, the contents of residual-P, the sum of $\mathrm{P}$, and TP in the humic layer were significantly greater in the upland than in the lowland and those of $\mathrm{NaOH}-\mathrm{P}_{\mathrm{i}}$ and $\mathrm{CHCl}-\mathrm{P}_{\mathrm{o}}$ in the mineral-I layer were significantly greater in the upland than in the lowland. The content of $\mathrm{NaOH}-\mathrm{P}_{\mathrm{i}}$ and $\mathrm{HCl}-\mathrm{P}_{\mathrm{i}}$ in the mineral-II layer was significantly lower in the lowland than in the upland.

The summation of $\mathrm{P}_{\mathrm{o}}\left(\mathrm{NaHCO}_{3}-\mathrm{P}_{\mathrm{o}}+\mathrm{NaOH}-\mathrm{P}_{\mathrm{o}}+\mathrm{cHCl}-\mathrm{P}_{\mathrm{o}}\right)$ was greater than $55 \%$ of the total extractable $\mathrm{P}$ in the humic layer; thus, $\mathrm{P}_{\mathrm{o}}$ was the major source in humic soils (Figures 1 and 2). $\mathrm{NaOH}-\mathrm{P}_{\mathrm{O}}$ and $\mathrm{NaHCO}_{3}-\mathrm{P}_{\mathrm{o}}$ were the most abundant $\mathrm{P}$ fractions in the humic layer. The summation of $\mathrm{P}_{\mathrm{i}}\left(\right.$ resin- $\left.\mathrm{P}_{\mathrm{i}}+\mathrm{NaHCO}_{3}-\mathrm{P}_{\mathrm{i}}+\mathrm{NaOH}-\mathrm{P}_{\mathrm{i}}+\mathrm{HCl}-\mathrm{P}_{\mathrm{i}}+\mathrm{cHCl}-\mathrm{P}_{\mathrm{i}}\right)$ was slightly greater than the summation of $P_{o}$ in mineral-I soils in the upland site. However, in the lowland, the summation of $P_{i}$ was slightly lower than that of $\mathrm{P}_{\mathrm{o}}$ in the mineral-I layer. Nevertheless, $\mathrm{NaOH}-\mathrm{P}_{\mathrm{o}}$ and $\mathrm{NaHCO}_{3}-\mathrm{P}_{\mathrm{o}}$ were still the major $\mathrm{P}$ fractions in the mineral-I soils. The $\mathrm{P}_{\mathrm{i}}$ forms were the dominant sources, and $\mathrm{HCl}-\mathrm{P}_{\mathrm{i}}$, as well as $\mathrm{CHCl}-\mathrm{P}_{\mathrm{i}}$, were the most abundant $\mathrm{P}_{\mathrm{i}}$ fractions in mineral-II soils.

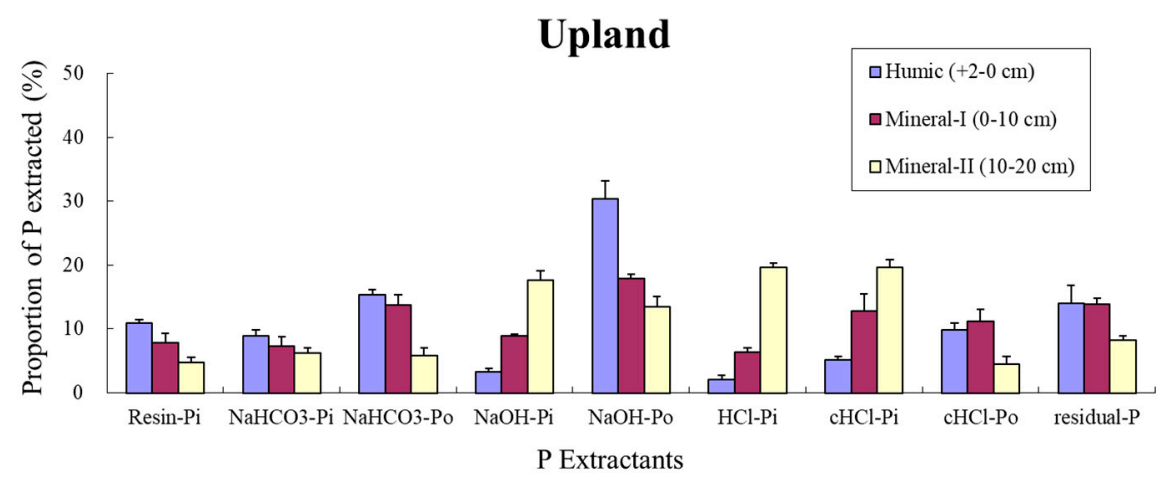

Figure 1. The proportion of $P$ fractions from the studied coastal forest upland soils determined by the sequential-chemical extraction method.

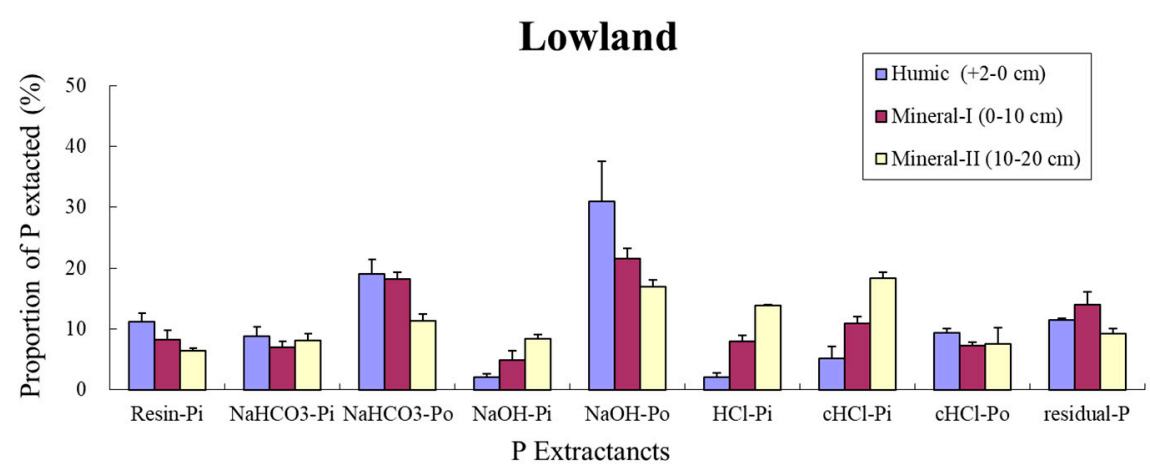

Figure 2. The proportion of $P$ fractions from the studied coastal forest lowland soils determined by the sequential-chemical extraction method.

\section{2. ${ }^{31}$ P-NMR Spectra Analyses}

The ${ }^{31} \mathrm{P}-\mathrm{NMR}$ spectra for NaOH-EDTA extracts detected inorganic orthophosphate, orthophosphate monoesters, orthophosphate diesters, and pyrophosphates in soil samples in this study site (Figures 3 and 4). ${ }^{31} \mathrm{P}-\mathrm{NMR}$ measurements revealed no phosphonate in any of the soil samples. The relative proportions and concentrations of each form of $\mathrm{P}$ were summarized in Figures 5 and 6 , and Table 3 . The forms of $P$ were grouped into $P_{i}$ compounds-including inorganic orthophosphate and pyrophosphates-and $\mathrm{P}_{\mathrm{o}}$ compounds, including orthophosphate monoesters, and orthophosphate diesters [14]. 


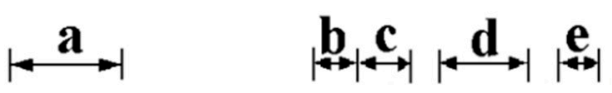

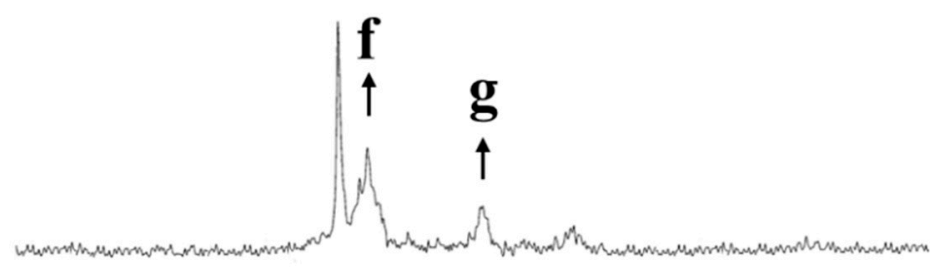

FH

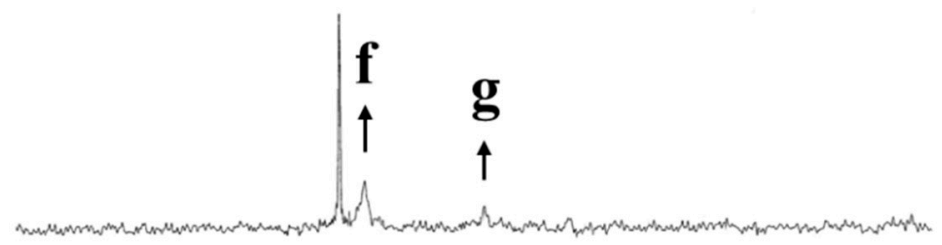

0-10 cm

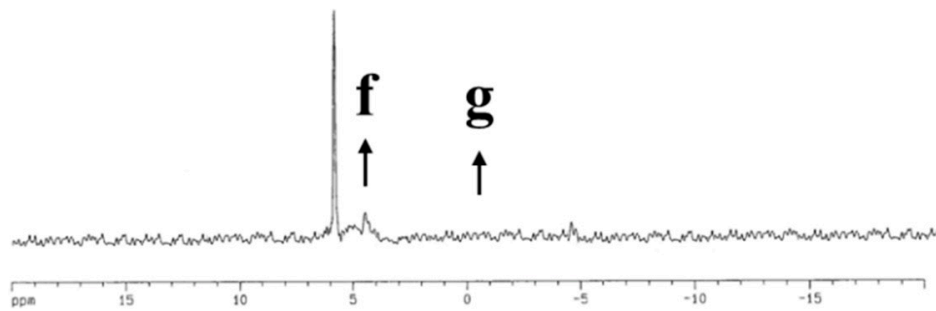

$10-20 \mathrm{~cm}$

Figure 3. The ${ }^{31} \mathrm{P}-\mathrm{NMR}$ spectra for $\mathrm{NaOH}-\mathrm{EDTA}$ extracts from the humic $(\mathrm{FH})$ and mineral layers $(0-10,10-20 \mathrm{~cm})$ of upland soils. a: phosphonate, b: inorganic orthophosphate, c: orthophosphate monoesters, d: orthophosphate diesters, e: pyrophosphate, f: myo-inositol hexakisphosphate, g: DNA.
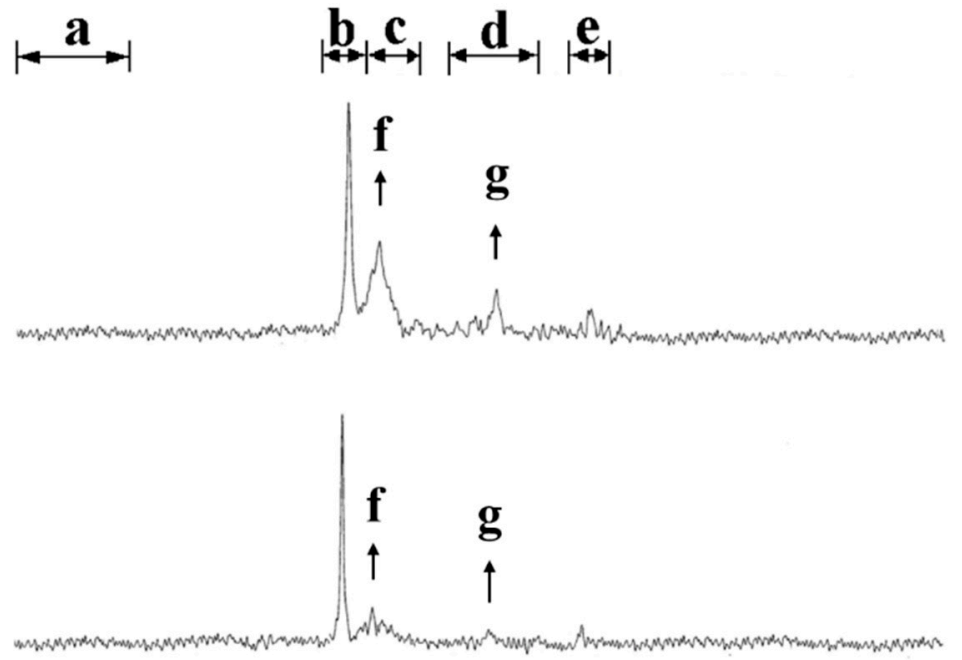

0-10 cm

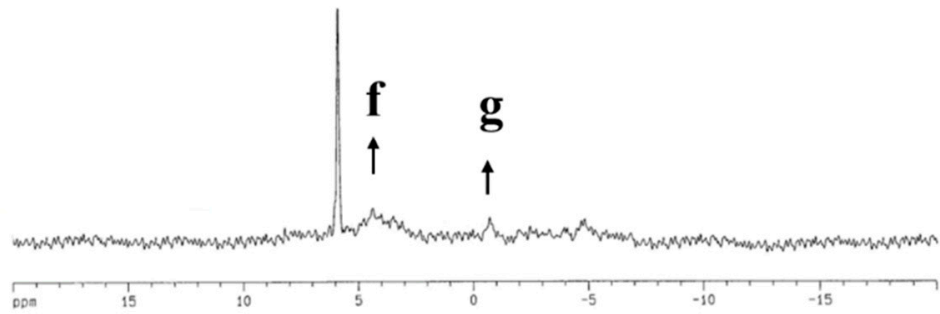

$10-20 \mathrm{~cm}$

Figure 4. The ${ }^{31} \mathrm{P}-\mathrm{NMR}$ spectra for $\mathrm{NaOH}-\mathrm{EDTA}$ extracts from the humic $(\mathrm{FH})$ and mineral layers $(0-10,10-20 \mathrm{~cm})$ of lowland soils. a: phosphonate, b: inorganic orthophosphate, c: orthophosphate monoesters, d: orthophosphate diesters, e: pyrophosphate. f: myo-inositol hexakisphosphate, g: DNA. 


\section{Upland}

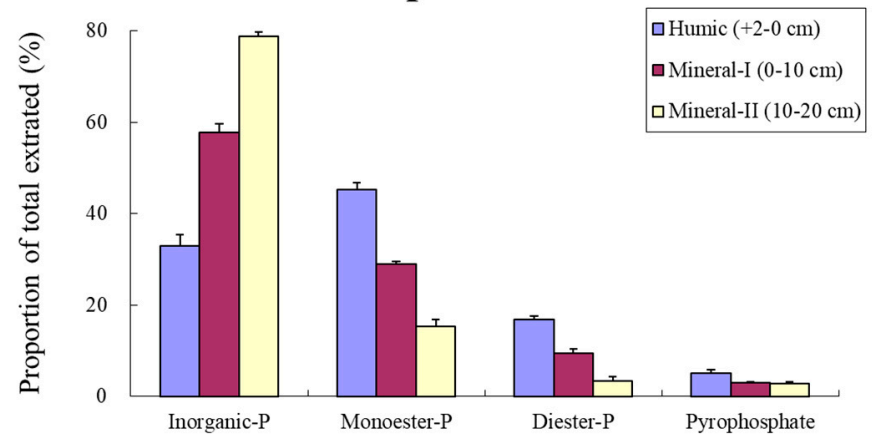

Figure 5. The ${ }^{31} \mathrm{P}-\mathrm{NMR}$ spectroscopy of the proportion of extracted $\mathrm{P}$ in various classes from humic and mineral layers of upland soil.

\section{Lowland}

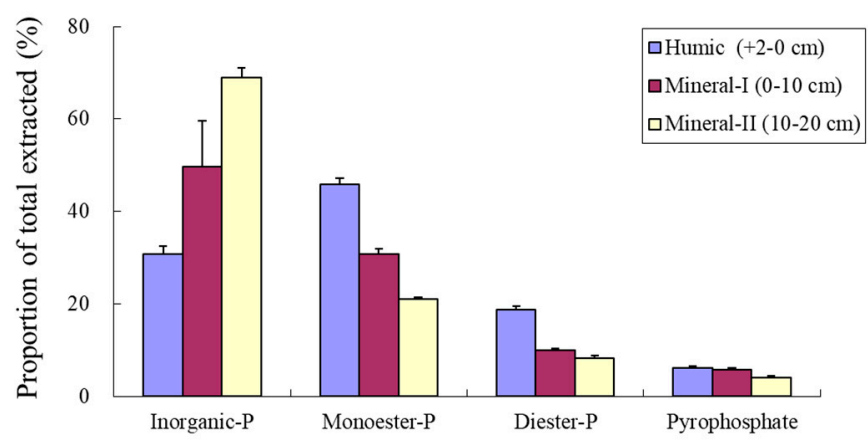

Figure 6. The ${ }^{31} \mathrm{P}-\mathrm{NMR}$ spectroscopy of the proportion of extracted $\mathrm{P}$ in various classes from humic and mineral layers of lowland soil.

Table 3. The summary of $\mathrm{P}$ concentrations (mean values, unit: $\mathrm{mg} \mathrm{kg}^{-1}$ ) and two-way ANOVA significance tests ( $p$-value) for ${ }^{31} \mathrm{P}-\mathrm{NMR}$ spectroscopy.

\begin{tabular}{|c|c|c|c|c|c|c|c|}
\hline Site & Layer & Inorganic-P & Monoester-P & Diester-P & Pyrophosphate & Sum of $P_{i}$ & Sum of $P_{0}$ \\
\hline \multirow{3}{*}{ Upland } & $\begin{array}{c}\text { Humic } \\
(+2-0 \mathrm{~cm})\end{array}$ & 209.2 & 287.5 & 106.9 & 32.7 & 242.1 & 394.2 \\
\hline & $\begin{array}{l}\text { Mineral-I } \\
(0-10 \mathrm{~cm})\end{array}$ & 219.0 & 110.2 & 35.9 & 11.4 & 230.5 & 146.0 \\
\hline & $\begin{array}{l}\text { Mineral-II } \\
(10-20 \mathrm{~cm})\end{array}$ & 217.0 & 42.3 & 9.5 & 7.6 & 224.7 & 51.7 \\
\hline \multirow{3}{*}{ Lowland } & $\begin{array}{c}\text { Humic } \\
(+2-0 \mathrm{~cm})\end{array}$ & 154.6 & 229.8 & 94.1 & 30.9 & 185.5 & 323.8 \\
\hline & $\begin{array}{l}\text { Mineral-I } \\
(0-10 \mathrm{~cm})\end{array}$ & 187.3 & 115.6 & 37.8 & 21.8 & 209.3 & 153.2 \\
\hline & $\begin{array}{l}\text { Mineral-II } \\
(10-20 \mathrm{~cm})\end{array}$ & 145.4 & 44.1 & 17.3 & 8.4 & 153.7 & 61.4 \\
\hline \multicolumn{8}{|c|}{ Two-Way ANOVA Significance Tests ( $p$-Value) } \\
\hline \multicolumn{2}{|c|}{ Effects } & Inorganic-P & Monoester-P & Diester-P & Pyrophosphate & Sum of $P_{i}$ & Sum of $P_{0}$ \\
\hline \multicolumn{2}{|c|}{ Locations } & $7.00 \times 10^{-3 *}$ & $3.85 \times 10^{-4 *}$ & $9.94 \times 10^{-6 *}$ & $1.63 \times 10^{-6 *}$ & $0.031 *$ & $9.44 \times 10^{-7 *}$ \\
\hline \multicolumn{2}{|c|}{ Layers } & $5.4 \times 10^{-9 *}$ & $7.48 \times 10^{-14 *}$ & $4.79 \times 10^{-12 *}$ & $2.19 \times 10^{-6 *}$ & $9.42 \times 10^{-9 *}$ & $1.41 \times 10^{-15 *}$ \\
\hline \multicolumn{2}{|c|}{ Location $\times$ Layer } & 0.313 & $4.74 \times 10^{-3 *}$ & $7.67 \times 10^{-4 *}$ & $4.94 \times 10^{-3 *}$ & 0.355 & $6.07 \times 10^{-5 *}$ \\
\hline
\end{tabular}

Inorganic orthophosphate was the major form of $\mathrm{P}_{\mathrm{i}}$ and the relative proportions increased significantly with soil depth (Figure 5 and Table 3). In addition, the proportions of inorganic orthophosphate were greater in the upland than lowland. 
The proportions were higher for orthophosphate monoesters than diesters in each soil layer. The orthophosphate monoesters were the predominant compounds of $\mathrm{P}_{\mathrm{o}}$. The relative proportions of orthophosphate monoesters and diesters significantly decreased with soil depth in both the upland and lowland. Additionally, the proportions of monoester-P and diester-P were lower in the upland than in the lowland. ${ }^{31} \mathrm{P}-\mathrm{NMR}$ results indicated that the proportions of monoester-P and diester-P in the mineral-II layer were significantly lower in the upland than in the lowland.

\section{Discussion}

\subsection{Sequential Chemical Extraction of Soil P}

Previous research at the same subtropical coastal sand dune forest site showed that the rapid decomposition of soil organic matter in the surface layers and the low adsorption capacity of organic $\mathrm{C}$ in sandy soil enhanced the eluviation process in the soil profile [40]. Thus, less organic matter accumulated at the deeper depth in this study, which was also identified by Chen and Chen [40]. In addition, $\mathrm{P}_{\mathrm{O}}$ concentrations were highest in the humic layer at this site, with a lower accumulation of organic matter in the mineral layers. Studies on tropical forests have also confirmed that $\mathrm{P}_{\mathrm{o}}$ (e.g., $\mathrm{NaOH}-\mathrm{P}_{\mathrm{o}}$ ) decreases with depth $[24,26]$.

Resin-P is associated with organic $\mathrm{C}$ content, which indicates that resin-P is mineralized from organic matter [29]. Because the organic $C$ content was the highest in the humic layer and decreased in the deeper layers (Table 1), the trend of the resin-P content was identical to organic $C$ content. Labile $P_{\mathrm{i}}$ was positively related to microbial uptake in soil $[12,41]$ and was replenished by dissolution or desorption mechanisms of less labile $P_{i}$ and the mineralization of $P_{o}[1,2]$. Consequently, the labile $P_{i}$ concentrations were also highest in the humic layer, and the labile $P_{i}$ content was associated with the $\mathrm{P}_{\mathrm{o}}$ content at both upland and lowland sites. The resistant $\mathrm{P}_{\mathrm{i}}$ content increased with depth, which is opposite to the labile $P_{i}$ pattern. The recalcitrant $P_{i}$ may have originated from the parent materials or accumulated in the soils over time because it could not be easily utilized by plants or microbes.

Negassa and Leinweber [29] suggested that the TP contents are similar in natural temperate, subtropical, and tropical soil ecosystems. However, the sand dune soils in this study might not fall into any of these categories. The range and contents of TP in our study (200-700 mg kg ${ }^{-1}$ soil) were narrower and lower than in temperate sand dune soils (200-900 mg kg-1 soil [3]; 300-1000 mg kg-1 soil [4]) compared to sand dunes of a similar age (less than 500 years). Since the plant species, soil types, climate, microbial activity, and sand dune development were different, the TP contents were different between our study area and temperate sand dune soils.

The oxidation-reduction states of minerals (e.g., iron and aluminum) affect the distribution and forms of $\mathrm{P}$ in soils $[8,9,27]$. For instance, $\mathrm{P}_{\mathrm{i}}$ was bound with Fe oxides strongly in oxidation conditions [27], but $\mathrm{P}$ was released from Fe minerals into soil solution in reduction conditions [8]. In addition, phosphorus sorption was affected by variations in mineralogy between soil layers, with a low sorption in organic matter-enriched top layers and high sorption in sesquioxide-enriched deep layers $[1,28]$. However, there was no significant correlation between most $\mathrm{P}$ forms and minerals except for the negative correlation between labile $\mathrm{P}$ and $\mathrm{Al}_{\mathrm{o}}$ (Table 4). Since water was well-drained in this sand dune soil, the minerals $\left(\mathrm{Fe}_{\mathrm{d}}, \mathrm{Fe}_{\mathrm{o}}, \mathrm{Al}_{\mathrm{d}}\right.$, and $\left.\mathrm{Al}_{\mathrm{o}}\right)$ did not accumulate in the deeper layers. In addition, the $\mathrm{Fe}_{\mathrm{d}}, \mathrm{Fe}_{\mathrm{o}}, \mathrm{Al}_{\mathrm{d}}$, and $\mathrm{Al}_{\mathrm{o}}$ concentrations only ranged from 0.6 to $6 \mathrm{mg} \mathrm{kg}^{-1}$ soil (Table 1 ), which is relatively narrower than in other studies (e.g., $0.4-63.0 \mathrm{mg} \mathrm{kg}{ }^{-1}$ soil for $\mathrm{Fe}_{\mathrm{d}}$ and $\mathrm{Fe}_{\mathrm{o}}$ in subtropical montane forests $[27,28]$ and $0.8-85 \mathrm{mg} \mathrm{kg}^{-1}$ soil for $\mathrm{Fe}_{\mathrm{d}}$ in tropical lands [9]). The mineral contents did not change distinctly among soil layers either; thus, the minerals might play a minor role in affecting the $\mathrm{P}$ distributions and forms in this study. 
Table 4. The summary of Pearson's correlation coefficients of $P$ forms and minerals.

\begin{tabular}{ccccc}
\hline Minerals & Labile $\mathbf{P}$ & Moderately Recalcitrant $\mathbf{P}$ & Recalcitrant $\mathbf{P}$ & Highly Recalcitrant $\mathbf{P}$ \\
\hline $\mathrm{Fe}_{\mathrm{d}}$ & -0.68 & 0.26 & 0.84 & -0.41 \\
$\mathrm{Fe}_{\mathrm{o}}$ & -0.75 & 0.24 & 0.90 & -0.50 \\
$\mathrm{Al}_{\mathrm{d}}$ & -0.45 & 0.33 & 0.48 & -0.44 \\
$\mathrm{Al}_{\mathrm{o}}$ & $-0.99^{*}$ & -0.1 & 0.95 & -0.89 \\
\hline
\end{tabular}

*: Significant difference $(p<0.05)$. Labile P: resin- $\mathrm{P}_{\mathrm{i}}+\mathrm{NaHCO}_{3}-\mathrm{P}$; Moderately recalcitrant P: NaOH-P; Recalcitrant

P: HCl-P + cHCl-P: Highly recalcitrant P: residual-P.

Spatial variability in the distribution of $\mathrm{P}$ pools and the total $\mathrm{P}$ were ascribed to parent materials and to redistribution in layers and landscapes [1]. Our previous study [42] confirmed that eolian aggradation was affected differently between the upland and lowland in this study area. Eolian aggradation occurred continually on the original surface soils, thereby leading to the multi-stratification of soil profiles in the upland. However, eolian aggradation was much reduced at the inland side of the lowlands. Because there were more sources of $P$ via eolian aggradation in the upland, the TP content was higher in the upland than lowland. The large molecules of the $\mathrm{P}$ forms (i.e., $\mathrm{NaOH}-\mathrm{P}_{\mathrm{i}}, \mathrm{HCl}-\mathrm{P}_{\mathrm{i}}, \mathrm{cHCl}-\mathrm{P}_{\mathrm{i}}$, and $\mathrm{cHCl}-\mathrm{P}_{\mathrm{o}}$ ) were less mobile than the small molecules of $\mathrm{P}$ forms (e.g., $\mathrm{NaHCO}_{3}-\mathrm{P}_{\mathrm{o}}$ ). In addition, residual-P was found in large molecular-weight complexes (e.g., lignin and organometallic content) [12,43], which does not decompose easily. As a result, the content of immobile $\mathrm{P}$ forms was higher in the upland than in the lowland in this study.

Cross and Schlesinger [44] and Solomon and Lehmann [2] found a large proportion of $\mathrm{P}_{\mathrm{o}}$ in highly weathered tropical soils. Because $\mathrm{P}_{\mathrm{o}}$ was the major form in both the humic layer and mineral-I layer in our lowland site, a weathering process may occur in these sand dune soils. Additionally, the content of $\mathrm{P}$ was similar in the humic and mineral-I layers. Since NaOH-P $\mathrm{O}_{\mathrm{o}}$ is mineralized slowly $[2,45]$, which explains the large amount of $\mathrm{NaOH}-\mathrm{P}_{\mathrm{o}}$ in the sand dune soils.

Sufficient moisture under warm climates increases the rate of microbial decomposition, which makes organic matter decompose rapidly [46], so a smaller amount of organic matter accumulated in the mineral-II layer in our site. Because the recalcitrant $P_{i}$ forms did not easily decompose, most of the $\mathrm{HCl}-\mathrm{P}_{\mathrm{i}}$ and $\mathrm{cHCl}-\mathrm{P}$ content accumulated in the mineral-II soils. Thus, the proportion of $\mathrm{P}_{\mathrm{i}}$ increased and that of $\mathrm{P}_{\mathrm{o}}$ decreased with depth in the sand dune forests at Houlong.

\section{2. ${ }^{31}$ P-NMR Spectra Analyses}

Decomposition processes are facilitated in a weakly acidic environment [20]. As the $\mathrm{pH}$ increased with depth, the organic matter decomposed rapidly in the deeper soil profiles in our site; thus, the proportion of inorganic orthophosphates increased with depth. Orthophosphate monoesters, not diesters, were the dominant species in the $P_{o}$ pools. These patterns are consistent with temperate coastal sand dune forests in New Zealand [3]. However, compared to the findings from Turner et al. [3] (inorganic-P: 17-39\%; monoester-P: 51-76\%), the proportion of inorganic-P and orthophosphate monoesters was higher and lower, respectively, in the mineral layers at our study site. Because the annual temperature was much higher and the distribution of rainfall was more uneven in our subtropical sand dune than in a temperate sand dune [3], $\mathrm{P}_{\mathrm{o}}$ decomposed rapidly because of microbial communities and this led to the reduced $\mathrm{P}_{\mathrm{o}}$ content observed in our study soils.

Orthophosphate monoesters are more stable than diester forms [1], so monoester-P could accumulate in soil over time [47]. Soil organic matter in the sandy soil is usually composed of particulate plant debris [48]; thus, we assumed that diester-P was plant-derived. Since the diester-P contents might be degraded during the ${ }^{31} \mathrm{P}-\mathrm{NMR}$ analyses [49,50], the comparisons between the contents of monoester-P and diester-P were not addressed specifically in this study.

Overall, the peak values of inorganic orthophosphate, pyrophosphate, and orthophosphate monoesters and diesters determined by ${ }^{31}$ P-NMR were similar or identical to previous findings $[17,20,51]$. The peak signal positioned around 4.5 ppm was myo-inositol hexakisphosphate $[11,52,53]$ and the peak signal centered at $-0.5 \mathrm{ppm}$ was DNA [14,46]. Myo-inositol hexakisphosphate and DNA represented 
the dominant forms of orthophosphate monoesters and diesters, respectively, in this study. Because myo-inositol hexakisphosphate is positively related to the plant-available $\mathrm{P}_{\mathrm{i}}$, the biologically available $\mathrm{P}$ is considered to regulate the quantity of myo-inositol hexakisphosphate under P-limited conditions [51]. These findings support that the orthophosphate monoester content had a similar trend as the labile $P_{i}$ content, which decreased with depth in soils at the study site. DNA in the diester form is favored in acidic soils $[11,54,55]$. However, the $\mathrm{pH}$ increased from the top to the bottom of the soil layers in this study area. Consequently, the proportion of diesters decreased with depth at both locations.

Most pyrophosphates came from the plant and microbial communities and were the hydrolysis products of polyphosphates [20]. Because pyrophosphates are hydrolyzed to orthophosphate rapidly through enzymatic mechanisms in soil [20], the proportion of pyrophosphates in our soil was low. Phosphonate is produced by bacteria (e.g., Bacillus cereus Frankland and Frankland) via enzymatic activity. However, bacteria are uncommon in acidic soil $[27,28,47]$. Thus, phosphonate was not detected in our sand dune forest soils.

Under aerobic conditions, the content of $\mathrm{P}_{\mathrm{o}}$ pools in soil from dominant to minor were monoester-P, diester-P, and phosphonate $[7,11]$. This pattern was also discovered in our study soils. Furthermore, abiotic reactions (e.g., sorption and occlusion) into minerals contributed to the preservation of orthophosphates [56].

\subsection{Sequential Chemical Extraction and ${ }^{31} P$-NMR Measurement Comparisons}

The differences in relative proportions of $\mathrm{P}_{\mathrm{o}}$ measured by sequential chemical extraction and ${ }^{31} \mathrm{P}-\mathrm{NMR}$ spectroscopy were less than $10 \%$ for all soil layers $\left(\mathrm{P}_{\mathrm{o}}\right)$ and humic layer $\left(\mathrm{P}_{\mathrm{i}}\right)$ in this study (Table 5). Negassa and Leinweber [29] found that the orthophosphate diester content was correlated with $\mathrm{NaHCO}_{3}-\mathrm{P}_{\mathrm{o}}$ content, which is easily mineralized and the orthophosphate monoester content was related to $\mathrm{NaOH}-\mathrm{P}_{\mathrm{O}}$ content, which is more stable. The proportions were consistent between $\mathrm{NaHCO}_{3}-\mathrm{P}_{\mathrm{o}}$ and diesters and between $\mathrm{NaOH}-\mathrm{P}_{\mathrm{o}}$ and monoesters in our study (Figures 2 and 3 and Figures 5 and 6). However, the proportion of $P_{i}$ was much higher by ${ }^{31} \mathrm{P}-\mathrm{NMR}$ spectroscopy than in the sequential chemical extraction. The differences in proportions between the two measurements were relatively higher for $\mathrm{P}_{\mathrm{i}}$ than $\mathrm{P}_{\mathrm{o}}$, especially in the mineral-I and mineral-II layers (Table 5).

Table 5. The mean proportions (\%) with the standard deviation of the total P extracted for inorganic $\mathrm{P}\left(\mathrm{P}_{\mathrm{i}}\right)$ and organic $\mathrm{P}\left(\mathrm{P}_{\mathrm{o}}\right)$ forms in the NaOH-EDTA extracts from soil samples as determined by sequential-chemical extraction and ${ }^{31} \mathrm{P}-\mathrm{NMR}$ spectroscopy.

\begin{tabular}{cccccc}
\hline \multirow{2}{*}{ Site } & \multirow{2}{*}{ Layer } & \multicolumn{2}{c}{$\mathbf{P}_{\mathbf{i}}$} & \multicolumn{2}{c}{$\mathbf{P}_{\mathbf{o}}$} \\
\cline { 3 - 6 } & & Chemical & ${ }^{31}$ P-NMR & Chemical & ${ }^{31}$ P-NMR \\
\hline \multirow{3}{*}{ Upland } & Humic $(+2-0 \mathrm{~cm})$ & $30.3 \pm 1.5$ & $38.2 \pm 2.9$ & $55.6 \pm 2.2$ & $62.2 \pm 1.6$ \\
& Mineral-I $(0-10 \mathrm{~cm})$ & $43.3 \pm 1.0$ & $60.8 \pm 2.1$ & $42.8 \pm 1.5$ & $38.5 \pm 1.4$ \\
& Mineral-II $(10-20 \mathrm{~cm})$ & $67.9 \pm 1.9$ & $81.7 \pm 1.0$ & $23.8 \pm 1.7$ & $18.8 \pm 0.5$ \\
\hline \multirow{3}{*}{ Lowland } & Humic $(+2-0 \mathrm{~cm})$ & $29.1 \pm 4.3$ & $37.0 \pm 2.0$ & $59.3 \pm 4.2$ & $64.6 \pm 1.2$ \\
& Mineral-I $(0-10 \mathrm{~cm})$ & $38.9 \pm 4.1$ & $55.6 \pm 9.5$ & $47.0 \pm 2.1$ & $40.7 \pm 1.2$ \\
& Mineral-II $(10-20 \mathrm{~cm})$ & $55.0 \pm 1.6$ & $72.9 \pm 2.4$ & $35.8 \pm 1.4$ & $29.1 \pm 0.7$ \\
\hline
\end{tabular}

The variances might be due to the occlusion of orthophosphate within large humic molecules [3]. Furthermore, sequential chemical extraction was found to be an indirect chemical method used to estimate organic P [20]. As stated by Tiessen and Moir [31], $P_{0}$ is estimated by the difference between $P_{t}$ and $P_{i}$ from each extract, so there are uncertainty factors (e.g., precipitation) when using sequential chemical extraction. The precision of ${ }^{31} \mathrm{P}-\mathrm{NMR}$ spectroscopy was also limited by background noise and the overlapping signals, especially for $P_{i}$ and orthophosphate monoesters [47]. In addition, paramagnetic impurities (e.g., Fe and Mn) restricted the quality of the ${ }^{31} \mathrm{P}-\mathrm{NMR}$ because they reduce the signal-to-noise ratio and amplify the intensity of the spinning sidebands [1]. Thus, these uncertainties caused differences between the two methods. 
Vestergren et al. [57] and Huang et al. [11] demonstrated that the use of 2- ${ }^{1} \mathrm{H}^{3}{ }^{31} \mathrm{P}$ correlation effectively enhances the resolution of overlapping signals after eliminating the paramagnetic impurities. This new technique was suggested for use in future applications of ${ }^{31} \mathrm{P}-\mathrm{NMR}$ spectroscopy. Overall, the proportions of $P_{i}$ and $P_{o}$ evaluated by sequential chemical extraction and ${ }^{31} \mathrm{P}-\mathrm{NMR}$ spectroscopy were mostly consistent in this study and the results were similar to those from other studies $[28,46,58]$.

\section{Conclusions}

The results of this study indicated that soils in our study site, a subtropical coastal sand dune forest site, were in a weathered environment. The P distribution and content significantly differed among the soil layers and between the upland and lowland sites by the variation in the elevation and eolian aggradation effects. The $\mathrm{P}_{\mathrm{o}}$ and labile $\mathrm{P}_{\mathrm{i}}$ content was highest in the humic layer and decreased with depth. However, the recalcitrant $P_{i}$ content had the opposite pattern. The content of recalcitrant $\mathrm{P}$ forms (e.g., $\mathrm{NaOH}-\mathrm{P}_{\mathrm{i}}, \mathrm{HCl}-\mathrm{P}_{\mathrm{i}}$, and $\mathrm{cHCl}$ ) was greater in the upland site than in the lowland site. ${ }^{31} \mathrm{P}-\mathrm{NMR}$ spectroscopy revealed that inorganic orthophosphate and monoester-P forms were the most abundant forms in this study. The proportions of $\mathrm{P}_{\mathrm{i}}$ and $\mathrm{P}_{\mathrm{o}}$ observed by sequential chemical extraction and ${ }^{31} \mathrm{P}$-NMR spectroscopy were mostly consistent. Because $\mathrm{P}$ distribution can be affected by microbial activity, the relationship between microbial processes and $\mathrm{P}$ content require further investigation.

Author Contributions: Conceptualization, C.Y.-C.; Data curation, C.-W.L. and C.-W.P.; Formal analysis, C.-W.P.; Funding acquisition, C.Y.-C.; Investigation, C.-W.L., G.T. and C.-W.P.; Methodology, C.Y.-C.; Project administration, C.Y.-C.; Supervision, C.Y.-C.; Validation, G.T.; Writing-original draft, C.-W.L. and C.-W.P.; Writing一review \& editing, G.T. and C.Y.-C.

Funding: The study was granted by Academia Sinica and Ministry of Sciences and Technology (MOST 107-2621-M-001-001), Taiwan.

Conflicts of Interest: The authors declare no conflict of interest.

\section{References}

1. Magid, J.; Tiessen, H.; Condron, L.M. Dynamics of organic phosphorus in soils under natural and agricultural ecosystems. In Humic Substances in Terrestrial Ecosystems; Piccolo, A., Ed.; Elsevier: Amsterdam, The Netherlands, 1996; pp. 429-466.

2. Solomon, D.; Lehmann, J. Loss of phosphorus from soil in semi-arid northern Tanzania as a result of cropping: Evidence from sequential extraction and ${ }^{31}$ P-NMR spectroscopy. Eur. J. Soil Sci. 2000, 51, 699-708. [CrossRef]

3. Turner, B.L.; Wells, A.; Condron, L.M. Soil organic phosphorus transformations along a coastal dune chronosequence under New Zealand temperate rain forest. Biogeochemistry 2014, 121, 595-611. [CrossRef]

4. McDowell, R.W.; Cade-Menun, B.; Stewart, I. Organic phosphorus speciation and pedogenesis: Analysis by solution ${ }^{31} \mathrm{P}$ nuclear magnetic resonance spectroscopy. Eur. J. Soil Sci. 2007, 58, 1348-1357. [CrossRef]

5. Chen, C.R.; Condron, L.M.; Sinaj, S.; Davis, M.R.; Sherlock, R.R.; Frossard, E. Effect of plant species on phosphorus availability in a range of grassland soils. Plant Soil 2003, 256, 115-130. [CrossRef]

6. Vance, C.P.; Uhde-Stone, C.; Allan, D.L. Phosphorus acquisition and use: Critical adaptations by plants for securing a nonrenewable resource. New Phytol. 2003, 157, 423-447. [CrossRef]

7. Condron, L.M.; Turner, B.L.; Cade-Menun, B.J. The chemistry and dynamics of soil organic phosphorus. In Phosphorus: Agriculture and the Environment; Sims, J.T., Sharpley, A.N., Eds.; ASA-CSSA-SSSA: Madison, WI, USA, 2005; pp. 87-121.

8. Lin, Y.; Bhattacharyya, A.; Campbell, A.N.; Nico, P.S.; Pett-Ridge, J.; Silver, W.L. Phosphorus fractionation responds to dynamic redox conditions in a humid tropical forest soil. J. Geophys. Res. 2018. [CrossRef]

9. Nishigaki, T.; Sugihara, S.; Kobayashi, K.; Hashimoto, Y.; Kilasara, M.; Tanaka, H.; Watanabe, T.; Funakawa, S. Fractionation of phosphorus in soils with different geological and soil physicochemical properties in southern Tanzania. Soil Sci. Plant Nutr. 2018, 64, 291-299. [CrossRef]

10. Mori, T.; Ishizuka, S.; Konda, R.; Wicaksono, A.; Heriyanto, J.; Hardjono, A.; Ohta, S. Phosphorus addition reduced microbial respiration during the decomposition of Acacia mangium litter in South Sumatra, Indonesia. Tropics 2015, 24, 113-118. [CrossRef] 
11. Huang, L.M.; Jia, X.X.; Zhang, G.L.; Shao, M.A. Soil organic phosphorus transformation during ecosystem development: A review. Plant Soil 2017, 417, 17-42. [CrossRef]

12. Hedley, M.J.; Stewart, J.W.B.; Chauhan, B.S. Changes in inorganic soil phosphorus fractions induced by cultivation practices and by laboratory incubations. Soil Sci. Soc. Am. J. 1982, 46, 970-976. [CrossRef]

13. Bowman, R.A.; Cole, C.V. An exploratory method for fractionation of organic phosphorus from grassland soils. Soil Sci. 1978, 125, 95-101. [CrossRef]

14. Newman, R.H.; Tate, K.R. Soil phosphorous characterization by ${ }^{31} \mathrm{P}$ nuclear magnetic resonance. Commun. Soil Sci. Plant Anal. 1980, 11, 835-842. [CrossRef]

15. Anderson, G. Assessing organic phosphorus in soil. In The Role of Phosphorus in Agriculture; Khasawneh, F.E., Sample, E.C., Kamprath, E.J., Eds.; American Society of Agronomy: Madison, WI, USA, 1980; pp. 411-431.

16. Condron, L.M.; Frossard, E.; Tiessen, H.; Newman, R.H.; Stewart, J.W.B. Chemical nature of organic phosphorus in cultivated and uncultivated soils under different environmental conditions. J. Soil Sci. 1990, 41, 41-50. [CrossRef]

17. Cade-Menun, B.J.; Liu, C.W.; Nunlist, R.; McColl, J.G. Soil and litter phosphorus-31 nuclear magnetic resonance spectroscopy: Extractants, metals, and phosphorus relaxation times. J. Environ. Qual. 2002, 31, 457-465. [CrossRef] [PubMed]

18. Kizewski, F.; Liu, Y.T.; Morris, A.; Hesterberg, D. Spectroscopic approaches for phosphorus speciation in soils and other environmental systems. J. Environ. Qual. 2011, 40, 751-766. [CrossRef] [PubMed]

19. Chen, T.-S.; Chiu, C.-Y.; Tian, G. Season dynamics of soil microbial biomass in coastal sand dune forest. Pedobiologia 2005, 49, 645-653. [CrossRef]

20. Dai, K.H.; David, M.B.; Vance, G.F.; Krayszowska, A.J. Characterization of phosphorus in a spruce-fir spodosol by phosphorous-31 nuclear magnetic resonance spectroscopy. Soil Sci. Soc. Am. J. 1996, 60, 1943-1950. [CrossRef]

21. Mori, T.; Ohta, S.; Ishizuka, S.; Heriyanto, J. Phosphorus application reduces $\mathrm{N}_{2} \mathrm{O}$ emissions from tropical leguminous plantation soil when phosphorus uptake is occurring. Biol. Fertil. Soils 2013, 50, 45-51. [CrossRef]

22. Mori, T.; Ishizuka, S.; Konda, R.; Wicaksono, A.; Heriyanto, J. Effects of phosphorus addition on $\mathrm{N}_{2} \mathrm{O}$ emissions from an Acacia mangium soil in relatively aerobic condition. Tropics 2016, 25, 117-125. [CrossRef]

23. Makarov, M.I.; Guggenberge, G.; Zech, W.; Alt, H.G. Organic phosphorus species in humic acids of mountain soils along a toposequence in the Northern Caucasus. J. Plant Nutr. Soil Sci. 1996, 159, 467-470. [CrossRef]

24. Spain, A.V.; Tibbett, M.; Ridd, M.; McLaren, T.I. Phosphorus dynamics in a tropical forest soil restored after strip mining. Plant Soil 2018, 427, 105-123. [CrossRef]

25. Yokoyama, D.; Mori, T.; Wagai, R.; Hiradate, S.; Kitayama, K. Characteristics of phosphorus fractions in the soils derived from sedimentary and serpentinite rockes in lowland tropical rain forests, Borneo. Soil Sci. Plant Nutr. 2018, 64, 218-221. [CrossRef]

26. del Arroyo, G.O.; Silver, W.L. Disentangling the long-term effects of disturbance on soil biogeochemistry in a wet tropical forest ecosystem. Glob. Chang. Biol. 2017, 24, 1673-1684. [CrossRef] [PubMed]

27. Shiau, Y.-J.; Pai, C.-W.; Tsai, J.-W.; Liu, W.-C.; Yam, R.S.W.; Chang, S.-C.; Chiu, C.-Y. Characterization of phosphorus in a toposequence of subtropical perhumid forest soils facing a subalpine lake. Forests 2018, 9, 294. [CrossRef]

28. Chiu, C.-Y.; Pai, C.-W.; Yang, K.-L. Characterization of phosphorus in sub-alpine forest and adjacent grassland soils by chemical extraction and phosphorus-31 nuclear magnetic resonance spectroscopy. Pedobiologia 2005, 49, 655-663. [CrossRef]

29. Negassa, W.; Leinweber, P. How does the Hedley sequential phosphorus fractionation reflect impacts of land use and management on soil phosphorus: A review. J. Plant Nutr. Soil Sci. 2009, 172, 305-325. [CrossRef]

30. Chang, E.-H.; Chen, C.-T.; Chen, T.-H.; Chiu, C.-Y. Soil microbial communities and activities in sand dunes of subtropical coastal forests. Appl. Soil Ecol. 2011, 49, 256-262. [CrossRef]

31. Tiessen, H.; Moir, J.O. Characterization of available P by sequential extraction. In Soil Sampling and Methods of Analysis; Carter, M.R., Ed.; Lewis Publishers: London, UK, 1993; pp. 75-86.

32. Zheng, Z.; Simard, R.R.; Lafond, J.; Parent, L.E. Pathways of soil phosphorus transformations after 8 years of cultivation under contrasting cropping practices. Soil Sci. Soc. Am. J. 2002, 66, 999-1007. [CrossRef]

33. Bowman, R.A.; Cole, C.V. Transformation of organic phosphorus substances in soil as evaluated by sodium-bicarbonate extraction. Soil Sci. 1978, 125, 49-54. [CrossRef] 
34. Williams, J.D.H.; Mayer, T.; Nriagu, J.O. Extractability of phosphorus from phosphate minerals common in soils and sediments. Soil Sci. Soc. Am. J. 1980, 44, 462-465. [CrossRef]

35. Murphy, J.; Riley, J.P. A modified single solution method for the determination of phosphate in natural waters. Anal. Chim. Acta 1962, 27, 31-36. [CrossRef]

36. Robinson, J.S.; Johnson, C.T.; Reddy, K.R. Combined chemical and ${ }^{31}$ P-NMR spectroscopic analysis of phosphorus in wetland organic soils. Soil Sci. 1998, 163, 705-713. [CrossRef]

37. Preston, C.M. Application of NMR to soil organic matter analysis: History and prospects. Soil Sci. 1996, 161, 145-166. [CrossRef]

38. Condron, L.M.; Davis, M.R.; Newman, R.H.; Cornforth, I.S. Influence of conifer on the form of phosphorus in selected New Zealand grassland soils. Biol. Fertil. Soils 1996, 21, 37-42. [CrossRef]

39. R Core Team. R: A Language and Environment for Statistical Computing. Available online: http://www.Rproject.org (accessed on 14 November 2018).

40. Chen, T.-H.; Chen, J.-S. Composition and distribution of soil organic matter in coastal forests at Szehu and Houlong, Taiwan. J. For. Sci. 2003, 18, 159-162.

41. Chauhan, B.S.; Stewart, J.W.B.; Paul, E.A. Effect of labile inorganic phosphate status and organic carbon additions on the microbial uptake of phosphorus in soils. Can. J. Soil Sci. 1981, 61, 373-385. [CrossRef]

42. Lin, Y.-T.; Whitman, W.B.; Coleman, D.C.; Chen, T.-H.; Chiu, C.-Y. Composition of bacterial communities in sand dunes of subtropical coastal forests. Biol. Fertil. Soils 2014, 50, 809-814. [CrossRef]

43. Schlichting, A.; Leinweber, P.; Meissner, R.; Altermann, M. Sequentially extracted phosphorus fractions in peat-derived soils. J. Plant Nutr. Soil Sci. 2002, 165, 290-298. [CrossRef]

44. Cross, A.F.; Schlesinger, W.H. A literature review and evaluation of the Hedley fractionation: Applications to the biogeochemical cycle of soil phosphorus in natural ecosystems. Geoderma 1995, 64, 197-214. [CrossRef]

45. Buresh, R.J.; Smithson, P.C.; Hellums, D.T. Building soil phosphorus capital in Africa. In Replenishing Soil Fertility in Africa; Buresh, R.J., Sanchez, P.A., Calhoun, F., Eds.; Soil Science Society of America: Madison, WI, USA, 1997; pp. 111-149.

46. Doolette, A.L.; Smernik, R.J.; McLaren, T.I. The composition of organic phosphorus in soils of Snowy Mountains region of south-eastern Australia. Soil Res. 2017, 55, 10-18. [CrossRef]

47. Tate, K.R.; Newman, R.H. Phosphorus fractions of a climosequence of soils in New Zealand tussock grassland. Soil Biol. Biochem. 1982, 14, 191-196. [CrossRef]

48. Amelung, W.; Zech, W.; Zhang, X.; Follett, R.F.; Tiessen, H.; Knox, E.; Flach, K.W. Carbon, nitrogen, and sulfur pools in particle-size fractions as influenced by climate. Soil Sci. Soc. Am. J. 1998, 62, 172-181. [CrossRef]

49. Cade-Menun, B.; Liu, C.W. Solution ${ }^{31}$ P-NMR spectroscopy of soils from 2005 to 2013: A review of sample preparation and experimental parameters. Soil Sci. Soc. Am. J. 2013, 78, 19-37. [CrossRef]

50. Doolette, A.L.; Smernik, R.J.; Dougherty, W.J. Spiking improved solution phosphorus-31 nuclear magnetic resonance identification of soil phosphorus compounds. Soil Sci. Soc. Am. J. 2009, 73, 919-927. [CrossRef]

51. Turner, B.L.; Mahieu, N.; Condron, L.M. Quantification of myo-inositol hexakisphosphate in alkaline soil extracts by solution ${ }^{31}$ P NMR spectroscopy and spectral deconvolution. Soil Sci. 2003, 168, 1-10. [CrossRef]

52. Turner, B.L.; Mahieu, N.; Condron, L.M. Phosphorus-31 nuclear magnetic resonance spectral assignments of phosphorus compounds in soil NaOH-EDTA extracts. Soil Sci. Soc. Am. J. 2003, 67, 497-510. [CrossRef]

53. Cade-Menun, B.J. Improved peak identification in ${ }^{31} \mathrm{P}-\mathrm{NMR}$ spectra of environmental samples with a standardized method and peak library. Geoderma 2015, 257-258, 101-114. [CrossRef]

54. Turner, B.L.; Blackwell, M.S.A. Isolating the influence of $\mathrm{pH}$ on the amounts and forms of soil organic phosphorus. Eur. J. Soil Sci. 2013, 64, 249-259. [CrossRef]

55. Cheesman, A.W.; Turner, B.L.; Reddy, K.R. Forms of organic phosphorus in wetland soils. Biogeosciences 2014, 11, 6697-6710. [CrossRef]

56. Celi, L.; Cerli, C.; Turner, B.L.; Santoni, S.; Bonifacio, E. Biogeochemical cycling of soil phosphorus during natural revegetation of Pinus sylvestris on disused sand quarries in Northwestern Russia. Plant Soil 2013, 367, 121-134. [CrossRef] 
57. Vestergren, J.; Vincent, A.G.; Jansson, M.; Persson, P.; IIstedt, U.; Grobner, G.; Giesler, R.; Schleucher, J. High-resolution characterization of organic phosphorus in soil extracts using $2 \mathrm{D}^{1} \mathrm{H}_{-}{ }^{31} \mathrm{P}$ NMR correlation spectroscopy. Environ. Sci. Technol. 2012, 46, 3950-3956. [CrossRef] [PubMed]

58. Jien, S.H.; Baillie, I.; Hu, C.-C.; Chen, T.-H.; Iizuka, Y.; Chiu, C.-Y. Forms and distribution of phosphorus in a placic podzolic toposequence in a subtropical subalpine forest, Taiwan. Catena 2010, 140, 145-154. [CrossRef] 